\title{
A REVIEW ON THE MALAYSIAN SUSTAINABLE PALM OIL CERTIFICATION PROCESS AMONG INDEPENDENT OIL PALM SMALLHOLDERS
}

\author{
PARTHIBAN KANNAN*; NUR HANANI MANSOR*; NAZIRA KHABIBOR RAHMAN*; \\ TAN SAY PENG* and SITI MARIAM MAZLAN**
}

\begin{abstract}
In recent years, palm oil faces various issues on the global market. Therefore, Malaysia launched the Malaysian Sustainable Palm Oil (MSPO) certification as the national scheme to systematically certify palm oil industry in Malaysia as an effort towards sustainable production as well to address some of the issues raised on the global market such as the requirement by importing countries for a completely certified sustainable palm oil supply chain. Various strategies have been developed to effectively certify independent smallholders such as the establishment of the Sustainable Palm Oil Clusters (SPOC). The aim of this article is to extend knowledge and experience gained towards MSPO certification approach among independent oil palm smallholders in Malaysia. It also provides a basis for operation frameworks towards certification approach for smallholders especially in developing countries. Apart from that, this article highlights the progress and national initiatives on the establishment of MSPO certification in Malaysia. It gives insight on the challenges and way forward of MSPO certification approach in Malaysia.
\end{abstract}

Keywords: Malaysian Sustainable Palm Oil (MSPO), independent oil palm smallholders, Sustainable Palm Oil Clusters (SPOC), certification.

Received: 25 July 2019; Accepted: 30 January 2020; Published online: 10 September 2020.

\section{INTRODUCTION}

Palm oil has been one of the major sources of oils and fats in the world (Kushairi et al., 2018). Oil palm crop is known to be highly productive compared to other competing crops due to its high yield per hectare as well as the low requirement of land area (Rival and Levang, 2014; Morley, 2015). Palm oil is well-known for its versatility which have been used in various sectors including non-food sector and well-known as a renewable energy feedstock other than its major role in providing food security to the world. Despite being the most efficient oil crop, palm oil has been

\footnotetext{
Malaysian Palm Oil Board,

6 Persiaran Institusi, Bandar Baru Bangi,

43000 Kajang, Selangor, Malaysia.

E-mail: parthiban@mpob.gov.my

** Solidaridad Network Asia,

L-2l-01, Connection Commercial,

Persiaran IRC 3, IOI Resort City,

62502 Putrajaya, Malaysia.
}

suffering from various anti-palm oil sentiments and increasing scrutiny over the years (Murphy, 2014). Some of the issues on the global market are on the allegations and misunderstandings about oil palm industry which are linked to intensive deforestation and destruction of biodiversity. There is a concern on the trend of increasing food standards which might act as a new trade barrier for developing countries (Augier et al., 2005; Brenton and Manchin, 2002; Ferrantino, 2006; Garcia and Poole, 2004). Increasing complexity of standards imposed on small farmers by global market creates some advantages as well as disadvantages among small farmers especially for export market (Humphrey, 2006). The palm oil industry faces various issues especially in Europe which started in 2015 with the Amsterdam Declaration which calls for a complete sustainable palm oil supply chain in Europe by 2020. Following that, the European Parliament Environmental (ENVI) report stated few recommendations on palm oil and deforestation with one of them is to eliminate 
the use of vegetable oils that cause deforestation as a component of biofuels in which it included palm oil. Then ENVI voted to ban palm oil biofuels from Europe from 2021, as part of the European Union (EU)'s Renewable Energy Directive (RED). Malaysia takes continuous effort to improve and elevate the palm oil industry to the global standard by addressing various requirement imposed by stakeholders as well as to cater for the growing global demands for vegetable oils. In 2018, the largest Malaysian palm oil exports markets were India with a total of 2.51 million tonnes followed by EU with a total of 1.91 million tonnes (Kushairi et al., 2019). Markets for certified sustainable palm oil (CSPO) in developed countries especially the EU have been on the increasing trends. In near future, these trends are expected to influence other traditional markets such as China, India and Pakistan to demand for CSPO. Oil palm which was initially brought in as an ornamental plant has become a major industry for Malaysia. After more than a century of commercial cultivation of oil palm, Malaysia currently has 5.85 million hectares of oil palm area (MPOB, 2018). Palm oil production is vital for the socioeconomic development of Malaysia especially the independent oil palm smallholders which account for $16.8 \%$ of the total planted area in Malaysia. Palm oil in Indonesia has been a powerful tool for poverty alleviation especially for smallholders by creating job opportunities and creates spin-off economic activities (Edwards, 2015).

\section{METHOD}

Desk research was conducted to review certification approach for smallholders in Malaysia. Primary data on readiness assessment among smallholders prior to joining the Malaysian Sustainable Palm Oil (MSPO) certification were gathered through survey questionnaire using an information and communications technology (ICT) tool. Apart from that, data on cost of certification as well as the frameworks on the MSPO certification and other relevant data were gathered from internal sources available at the Malaysian Palm Oil Board (MPOB).

\section{MSPO Certification}

Although the word sustainability can be traced back much earlier in history, it becomes widely used after the Report of the World Commission on Environment and Development (1987) which describes it as development that meets the needs of the present without compromising the ability of future generations to meet their own needs. Three fundamentals of sustainable development were highlighted which consist of environmental protection, social responsibility and economic practices. Since then, various certification standards have been developed all over the world using sustainability as their fundamentals (DeFries et al., 2017; Potts et al., 2014).

In Malaysia, there are several palm oil certification standards currently being used. However, the most common standards are MSPO, Roundtable on Sustainable Palm Oil (RSPO), and International Sustainability and Carbon Certification (ISCC). RSPO is an international oil palm certification scheme developed in 2004 which consists of members from all stages of oil palm supply chain. ISCC was introduced in 2010 mainly for certification of palm oil used as a feedstock for biofuels. Other than that, Indonesia has introduced their own certification scheme known as the Indonesian Sustainable Palm Oil (ISPO) in 2011 to certify palm oil industry in Indonesia.

The report on United Nations Conference on Environment and Development (1992) on Agenda 21 consists of a comprehensive plan of action, recommended by UN summit to be taken globally. In Agenda 21, article 8.6 states that, countries could develop systems for monitoring and evaluation of progress towards achieving sustainable development by adopting indicators that measure changes across economic, social and environmental dimensions. Standards developed in different parts of country or geographical area might not be effective to other countries if the standard does not cater for local conditions. Local requirement and crop specific standards can be further incorporated into a generic standard to make sure the criteria are not superfluous (Dankers and Liu, 2003). Therefore, in 2013, MSPO certification scheme was launched as the national scheme for Malaysia to systematically certify palm oil industry in Malaysia. Since then, MSPO implementation has been on a voluntary basis until the government announced its mandatory implementation in 2017. Initially, the mandatory timeline for companies that have been certified under RSPO need to obtain MSPO certification by 31 December 2018 while companies without RSPO certification were given extended time until 30 June 2019. Independent and organised smallholders were given until 31 December 2019 to obtain MSPO. However, recently the timeline were revised to a single timeline where the implementation of MSPO certification for all categories would be made mandatory by 31 December 2019. In 2014, an independent non-profit organisation known as the Malaysian Palm Oil Certification Council (MPOCC) was established as the scheme owner to implement and operate the MSPO certification scheme in Malaysia.

Initially, MSPO was initiated by MPOB in 2010 where MPOB is the authorised Standards-Writing Organisation (SWO) appointed by SIRIM Bhd which 
is the national standards development agency to develop the standards. Prior to MSPO, MPOB has been implementing the MPOB Codes of Practice (CoP) since 2007 to assist the industry on the best practices throughout the palm oil supply chain. The MSPO standards was developed by MPOB through a standards development process under the purview of the Department of Standard Malaysia (DSM) which is the National Standards Body and the National Accreditation Body with inputs from relevant stakeholders of the oil palm industry. MSPO scheme contains four parts such as MSPO 2530-1:2013 Part 1: General principles, MSPO 25302:2013 Part 2: General principles for independent smallholders, MSPO 2530-3:2013 Part 3: General principles for oil palm plantations and organised smallholders, and MSPO 2530-4:2013 Part four: General principles for palm oil mills. In addition, MSPO Supply Chain Certification Standard (SCCS) was launched by MPOCC to extend the standard to the downstream industry. MSPO is seen as the Malaysia's answer to the Amsterdam Declaration which wants a complete certified sustainable palm oil supply chain in Europe by 2020 with the hope that MSPO is accepted as a certification system in Europe. The Amsterdam Declaration is currently signed by European countries of Denmark, Germany, Norway, Netherlands, the United Kingdom, France and Italy to show their commitment to support a fully sustainable palm oil supply chain by 2020 .

According to the International Organisation for Standardisation (ISO), certification means the provision by an independent body of written assurance (a certificate) that the product, service or system in question meets specific requirements. To achieve this, the auditing and certification process are carried out by independent certification bodies (CB) which are subject to accreditation by DSM in accordance to the international standard of MS ISO/IEC 17011 (Ainie et al., 2015). Currently, there are $13 \mathrm{CB}$ consisting of both international and local companies involved in certifying independent smallholders in Malaysia. Application of MSPO part 2 for independent smallholders are currently under the purview of MPOB. Meanwhile, application of MSPO part 3 for oil palm plantations and organised smallholders and MSPO part 4 for palm oil mills are currently under the responsibility of MPOCC.

\section{Concept of Sustainable Palm Oil Clusters (SPOC)}

As of April 2019, there are 262724 independent smallholders owning 1015524 ha of oil palm in Malaysia. Independent smallholding are defined as those who own oil palm land less than 40.46 ha or in aggregate amount of less than 40.46 ha. These smallholders are scattered all over the country with various age profile and practices while managing their oil palm land on their own. The average land holding of independent oil palm smallholders in Peninsular Malaysia is 2.3 ha (Parthiban et al., 2017b). In this case, certification cost might be high if smallholders were to be certified individually (AgroEco and Grolink, 2008). In 2002, MPOB has established extension services known as Tunjuk Ajar dan Nasihat Sawit (TUNAS) to provide extension services on oil palm to independent smallholders. Current ratio of TUNAS extension agent to smallholders is 1:1500 which poses some challenges to provide extension services to all smallholders especially for MSPO certification which has been made mandatory by 31 December 2019. One of the strategies of MPOB to prepare smallholders for MSPO certification is by establishing SPOC all over the country to group smallholders within a small group of between 1000-2000 smallholders for each group (Table 1). This grouping enables them to be certified together under a single certificate. Each SPOC will be managed by one TUNAS officer who acts as the Group Manager (GM) to ensure that all individual members comply with the standard (Figure 1). Every four to five SPOC will be further managed by one head of TUNAS officer who acts as an Internal Control System (ICS) officer who will oversee and establish the general control system for every SPOC. In addition, external groups such as dealers, mills and cooperatives also can be formed and they can act as a GM for smallholders to be certified under MSPO. Eventually, it is up to the decision of individual smallholders to join any one of the groups in order to be certified under MSPO.

Several countries have successfully implemented group certification to enable farmers to be certified under a standard. Thailand has established Good Aquaculture Practice standard for shrimp production via group certification to enable shrimp farmers to access the EU market (Laila et al., 2011). In India, better management practices (BMP) for shrimp production were successfully adopted by farmers via the formation of clusters (Philips et al., 2008).

TABLE 1. DISTRIBUTION OF SMALLHOLDERS AND SPOC IN MALAYSIA (data as of April 2019)

\begin{tabular}{clrcr}
\hline No. & \multicolumn{1}{c}{ State } & $\begin{array}{r}\text { No. of } \\
\text { SPOC }\end{array}$ & $\begin{array}{r}\text { No. of } \\
\text { smallholders }\end{array}$ & $\begin{array}{c}\text { Hectarage } \\
\text { (ha) }\end{array}$ \\
\hline 1 & Johor & 43 & 80869 & 231621 \\
2 & Kedah and Perlis & 3 & 6485 & 28315 \\
3 & Pulau Pinang & 1 & 1918 & 9443 \\
4 & Perak & 23 & 46689 & 127763 \\
5 & Selangor & 11 & 21429 & 45464 \\
6 & Negeri Sembilan & 4 & 6051 & 27347 \\
7 & Melaka & 2 & 3179 & 13400 \\
8 & Pahang & 9 & 13489 & 55426 \\
9 & Terengganu & 3 & 3702 & 13523 \\
10 & Kelantan & 2 & 2157 & 7065 \\
11 & Sabah & 29 & 35338 & 220911 \\
12 & Sarawak & 32 & 41418 & 235246 \\
\hline & Total & 162 & 262724 & 1015524 \\
\hline
\end{tabular}

Note: SPOC - Sustainable Palm Oil Clusters. 


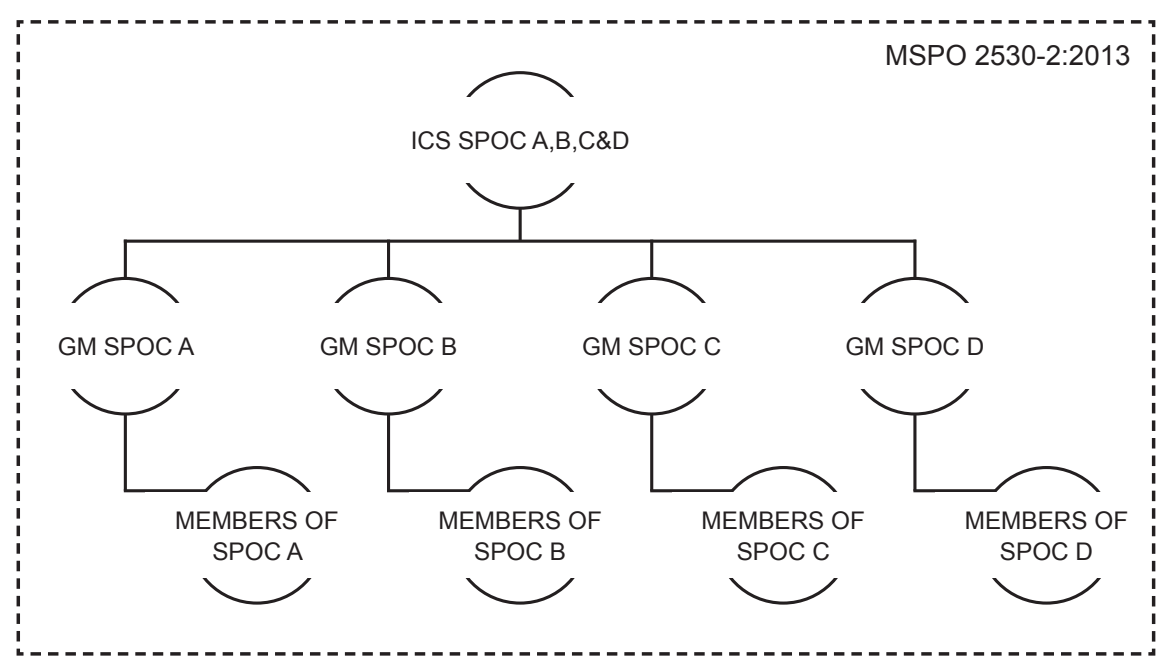

Figure 1. Concept of Sustainable Palm Oil Clusters (SPOC) under MPOB.

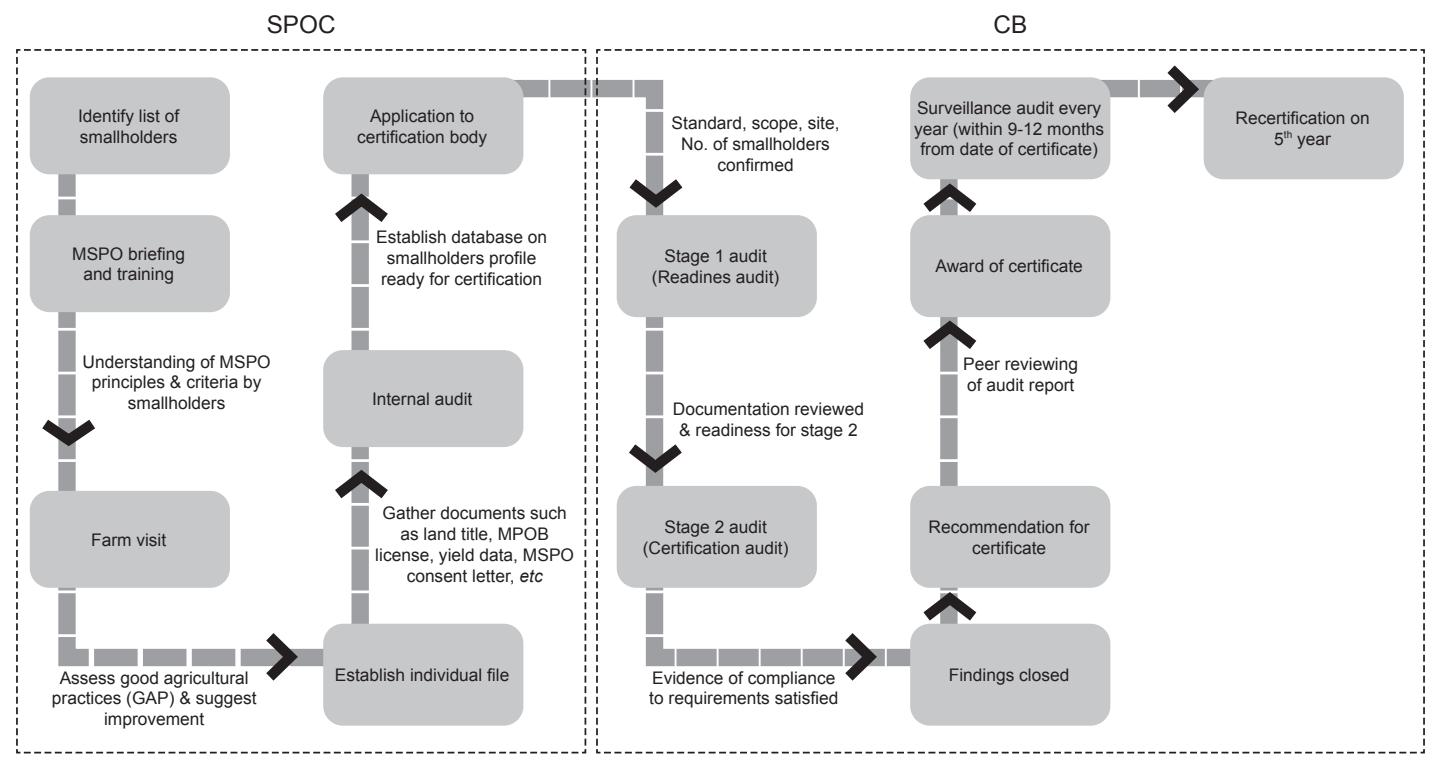

Figure 2. Frameworks of the Malaysian Sustainable Palm Oil (MSPO) certification for independent smallholders.

\section{Certification Process}

The process of certification starts when the GM identifies list of smallholders and invites them to join MSPO briefing and training (Figure 2). Once the GM gets smallholders consent to join MSPO, further visit to their farms are organised to assess the extent of Good Agricultural Practice (GAP) at their farms. Suggestion of any improvement on their existing GAP is explained and time is given for them to implement all the suggestions. At the same time, various training and extension activities would be conducted to expose smallholders to the principles and criteria of MSPO with the involvement of other agencies such as the Department of Occupational Safety and Health, the Department of Environment, the Department of Wildlife and National Parks and others. Individual file of each smallholders would be created containing basic documents such as land title, MPOB license, yield data, MSPO consent letter and others. A database containing detailed information of all the smallholders who are ready to be certified for each SPOC would be created by the GM. An internal audit would be conducted to further assess the level of readiness before inviting external certification body to carry out the auditing process. SPOC would undergo phase 1 auditing process to assess the level of readiness before proceeding to phase 2 audit. Random sampling would be used to select members from the SPOC based on risk factor. The $\mathrm{CB}$ would conduct the audit based on requirements stated in part two of the MSPO for independent smallholders which contains 7 principles, 22 criteria and 33 indicators. 
Once completed, the CB would undergo various steps before awarding MSPO certificate which is valid for five years. From there on, surveillance audit would be conducted each year before recertification audit on the fifth year. The GM would continue all the processes above to add new smallholders to the clusters in preparation for audit each year.

\section{Progress and National Initiatives of MSPO Certification}

To date, 162 SPOC have been established all over the country to cover all the 262724 of smallholders in Malaysia (Figures 3 to 5). As of July $2020,30.28 \%$ of the total smallholders have been certified under 162 SPOC covering 75890 smallholders with 305348 ha. Certifying all the smallholders has proven to be a great challenge compared to bigger plantations as these smallholders are independent in managing their land without any structured management. However, the government of Malaysia is intensifying the effort to certify all the smallholders in Malaysia.

Certification often resulted in high cost as demonstrated by Basiron et al. (2016) which reported the high cost of pursuing RSPO certification in Malaysia. Similarly, Brandi et al. (2015) reported that one of the challenges in certifying small producers under RSPO is the financial barrier. Smallholders can be further left out if they are not able to afford the high cost of certification (Defries et al., 2017). Therefore, the Malaysian government has allocated RM 30 million which was announced in the 2019 budget to fully fund expenses for MSPO audit including training for independent smallholders. Total cost per smallholder to be certified under MSPO is approximately between RM 1000 to RM 1200 calculated based on 500 smallholders for each SPOC which include the cost of auditing, training and to provide Personal Protective Equipment (PPE) as well as shelves to keep herbicides or pesticides.

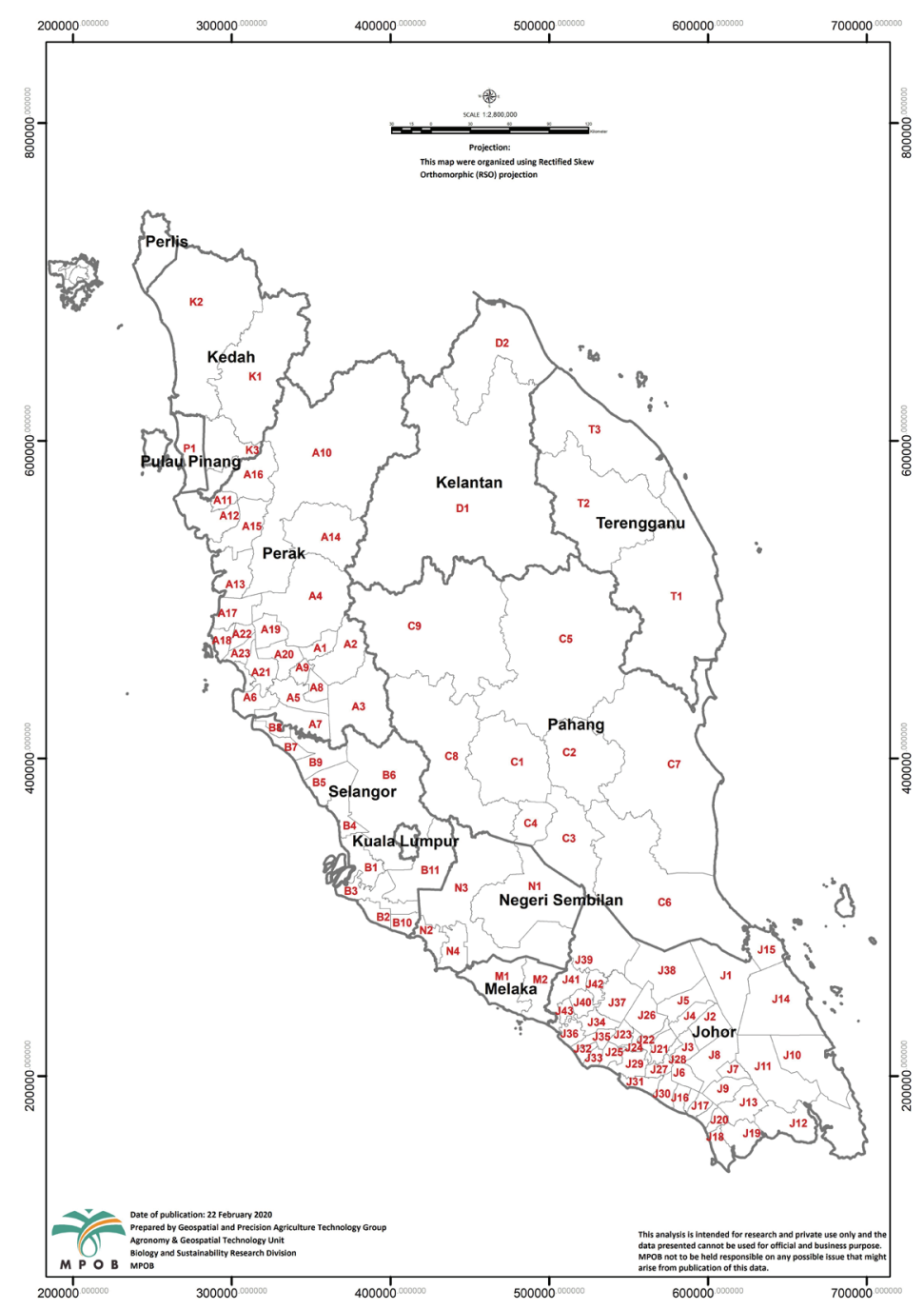

Note: The indication of alphabets in the map represent different states in Malaysia while the numbering indicates numbers of SPOC in each state. 


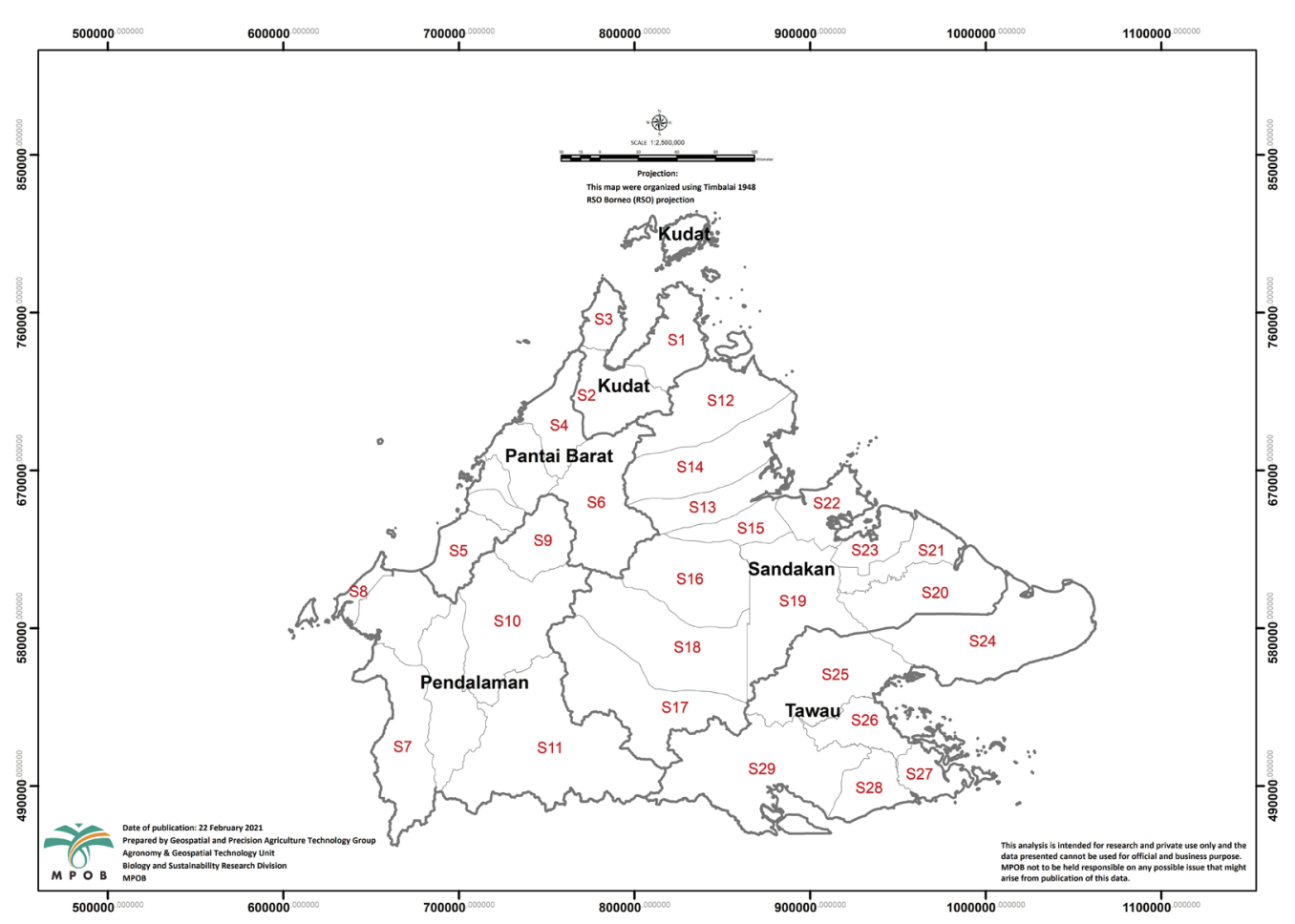

Note: The indication of alphabets in the map represent different states in Malaysia while the numbering indicates numbers of SPOC in each state.

Figure 4. Distribution of Sustainable Palm Oil Clusters (SPOC) in Sabah.

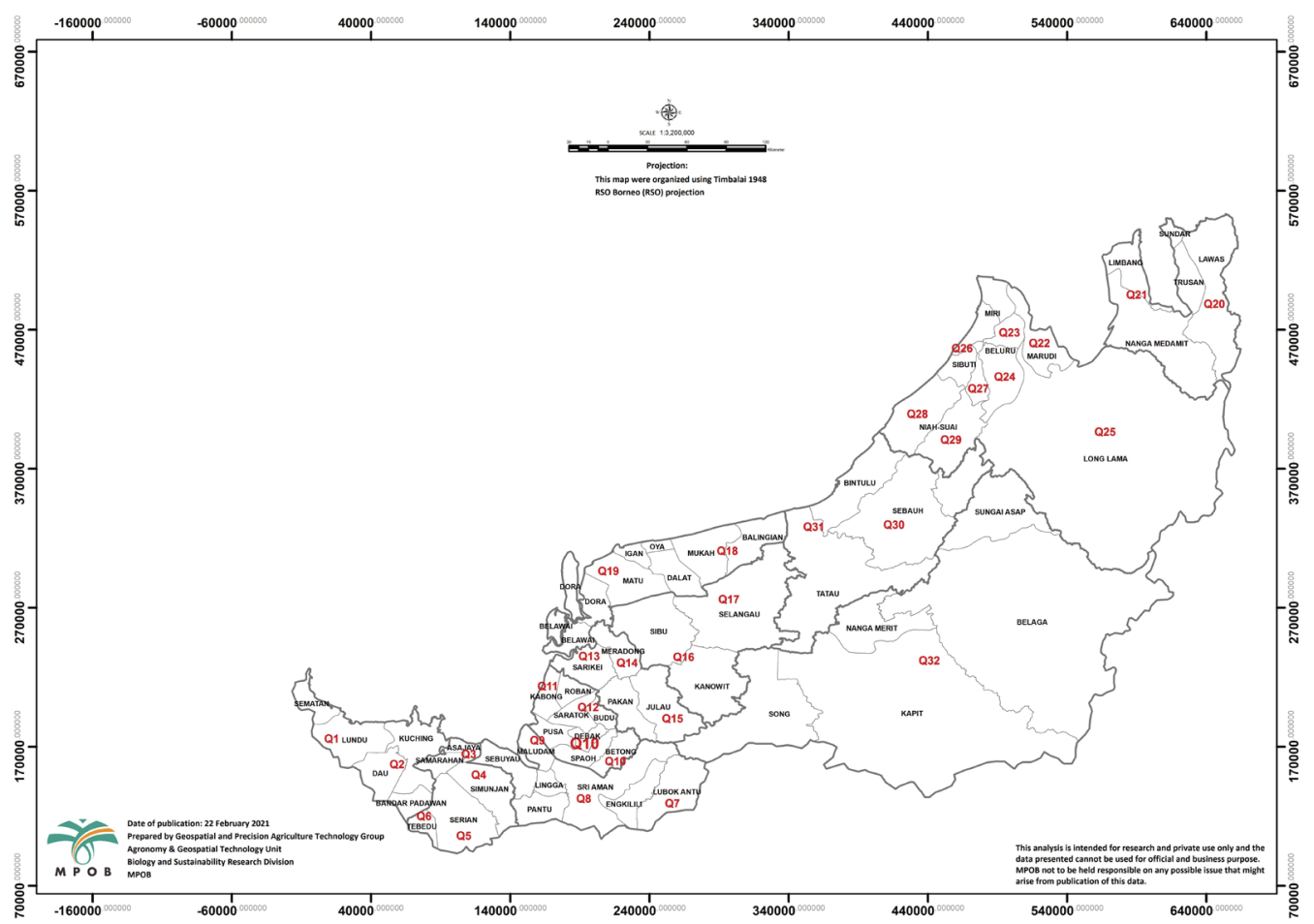

Note: The indication of alphabets in the map represent different states in Malaysia while the numbering indicates numbers of SPOC in each state.

Figure 5. Distribution of Sustainable Palm Oil Clusters (SPOC) in Sarawak. 


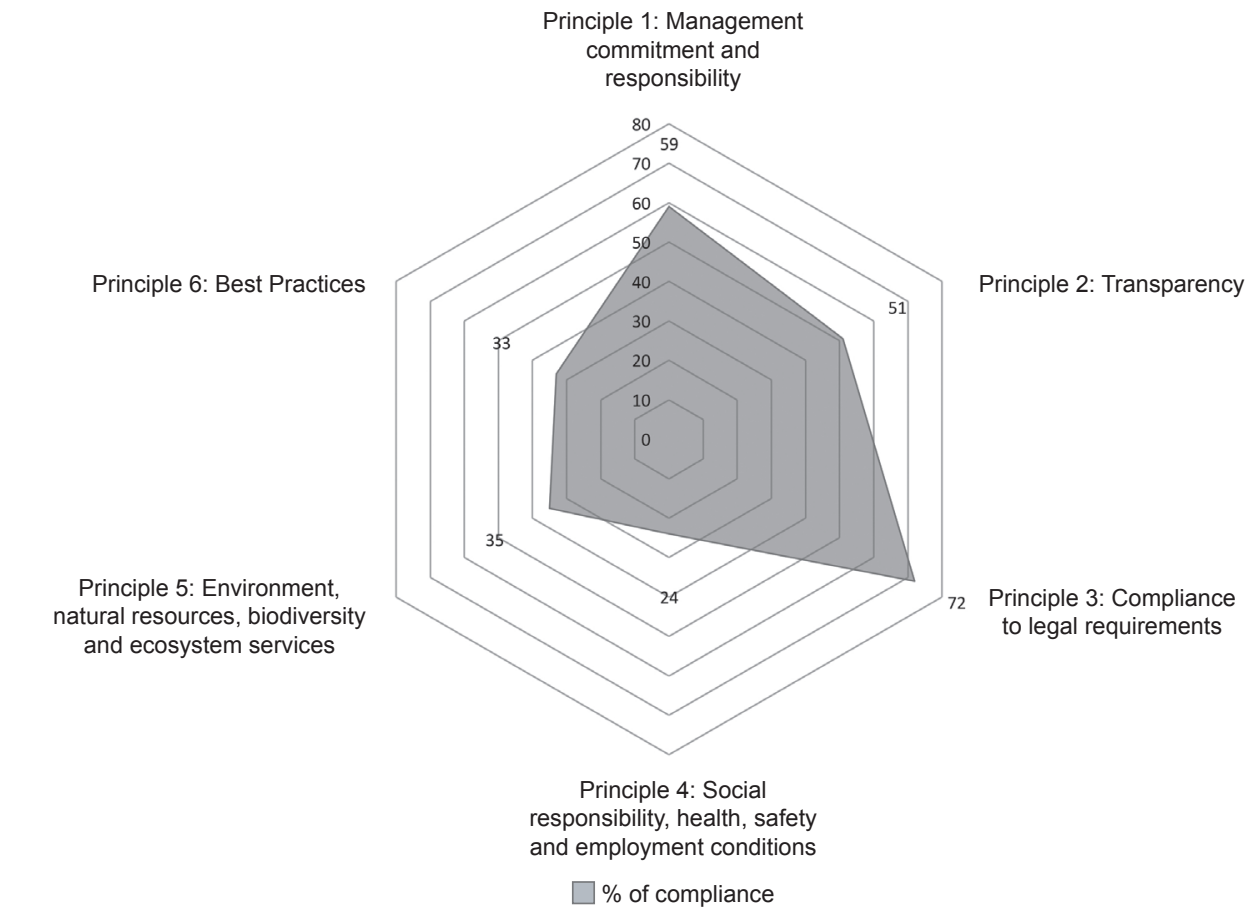

Figure 6. Graph on the level of readiness compliance on Malaysian Sustainable Palm Oil (MSPO) principles among smallholders who achieved high level compliance (80\%-100\%).

Other than that, MPOB together with Solidaridad which is an international network organisation have collaborated to develop an ICT tool to assess the level of compliance among smallholders in terms of readiness with MSPO prior to certification. Based on early readiness assessment conducted on 100 smallholders prior to joining MSPO certification in one of the SPOC found that majority $(52 \%)$ of the smallholders have moderate level of compliance towards MSPO. This was followed by $46 \%$ of the smallholders in the category of high level compliance while the rest $(2 \%)$ belongs to the category of low level compliance towards MSPO. Principle 7 on development of new planting was not applicable as all the respondents have already cultivated oil palm. Further analysis among the respondents who achieved high level compliance $(80 \%-100 \%)$ found that majority of the smallholders recorded high level of compliance (72\%) on Principle 3 regarding compliance to legal requirements while Principle 4 on social responsibility, health, safety and employment conditions recorded low level of compliance at only $24 \%$ (Figure 6). This might be due to the fact that most of the respondents have valid land title and MPOB licenses therefore they were able to comply on most of the criteria under Principle 3. However, low level compliance on Principle 4 might be due to the fact that most of the oil palm smallholders in Malaysia were hiring parttime labour to conduct their farm works (Parthiban et al., 2017b). Therefore, they might not be aware on the requirement on employee's condition as well as the safety and health requirement.

\section{Challenges and Future Strategies}

Based on early assessment on all the audit reports prepared by CB in 82 SPOC covering 5586 smallholders with 20441 ha as of December 2018, it was found out that majority of the SPOC have common non-compliance on MSPO clause 4.2.1 on traceability. Earlier study reported that most of the oil palm smallholders in Malaysia are not practicing proper record keeping (Ayat et al., 2008; Parthiban et al., 2017a). For the purpose of auditing, normally SPOC GM has to rely on dealers to provide records of fresh fruit bunches (FFB) transaction of smallholders for each audit; this is not efficient. There should be a real-time computerised system to record FFB transaction among smallholders in real time for efficient data gathering (Parthiban et al., 2017a). The second most common non-compliance on MSPO was raised for clause 4.5.3 on waste management and disposal. Smallholders often lack the awareness on the proper way to dispose empty chemical containers. Awareness training on the proper disposal should be intensified and more affordable collecting agents should be identified for each SPOC.

Smallholders are facing a lot of challenges, especially to meet the global and national certification standards in line with the global demand for sustainable palm oil. Therefore, it is necessary to have a harmonisation between different sustainability certification systems with a mutually accepted standard criteria. Other than that, land issues especially requirement on land use for different crops have to be addressed effectively 
at a higher administrative levels perhaps via interministerial and state government cooperation to find an effective solution. Low voluntary participation for MSPO certification among smallholders presents a real challenge for extension agent to convince them on the importance of MSPO. A more comprehensive license act to include MSPO requirement during every license application or renewal will be more effective to increase the MSPO awareness among smallholders.

A better assessment system needs to be in place to evaluate the performance of smallholders. Extension agent needs to identify the training needs on MSPO and assess their progress after each training via score assessment to better evaluate their performance. Introduction of any solution in the name of certification must be sustainable and be profitable in an effort to make sustainable palm oil to become the new norm among smallholders. Certification process requires significant costs, time and effort especially for smallholders to be successfully certified. As a longterm initiative, certification should outweigh the costs so that producers especially smallholders find it worthwhile to get certified. Amekawa (2013) reported that one of the factors that limit producers from adopting certification is because of the lack of economic benefits associated with getting the certificate. Smallholders are giving less attention to non-economic benefits of certification such as social and environmental aspect rather than the economic benefits (Nia et al., 2015).

Palm oil share is on the rise in the oils and fats global market, however, the premium price on certified palm oil is still largely very low (Byerlee and Rueda, 2015). The current mechanism of assistance from the government for MSPO certification might not be sustainable in the long run. Therefore, it needs to have a long-term mechanism in place to finance the cost of certification without government fund such as through cooperative establishment among smallholders themselves. Other suggestion is to give more focus to implement MSPO certification through existing clusters such as dealers, mills, associations and contractors since these clusters have already established relationship with smallholders.

Other than that, acceptance to change among smallholders is low as most of the oil the palm smallholders in Malaysia are older farmers with the average age of 54 years old (Parthiban et al., 2017b). Sometimes, they found it hard to accept any changes and recommendations by extension agents based on principle and criteria of MSPO. Apart from that, they also normally hire workers or outsource work to contractors or dealers. In order to be effective in increasing awareness on MSPO, all the stakeholders especially dealers and contractors need to be involved in MSPO initiative as they are part of the supply chain.
Although Malaysia is moving fast to be certified under MSPO, however there should be no compromise on the quality of process leading towards getting the MSPO certificate especially the auditing process by the $\mathrm{CB}$. Fontaine et al. (2008) also suggested that increased competition between certification agencies might result in lower certification cost especially in developing countries where it is generally expensive. There is no harm to encourage the development of more competent $\mathrm{CB}$ to conduct MSPO certification. However, strict requirement for competency and accreditation must be imposed to make sure the quality is not compromised. There should be a reliable control procedure to provide check and balance in maintaining higher standard in MSPO certification.

\section{CONCLUSION}

The MSPO standards were developed through a standards development process with inputs from relevant stakeholders of the oil palm industry to better suit the local requirements. Low ratio of extension officer to smallholders poses some challenges to provide extension services to all smallholders especially for MSPO certification. Therefore, MPOB has established 162 SPOC all over the country to group smallholders within a small group of between 1000-2000 smallholders to enable them to be certified together under a single certificate. As of July 2020, 30.28\% of the total smallholders have been certified. The process of certification starts with the GM identifying list of smallholders, conduct training, visit to farm to assess the extent of GAP, establish individual file and finally invite the $\mathrm{CB}$ to conduct the audit before awarding the certificate. Based on early readiness assessment prior to joining MSPO, it was found out that majority of the smallholders have moderate level of compliance towards MSPO with most of them having common non-compliance on MSPO clauses related to traceability due to lack of proper record keeping. Some of the recommendation is to have a harmonisation between different sustainability certification systems with a mutually accepted standard criteria, establish a comprehensive license act to include MSPO requirement, address land use requirement via inter-ministerial and state government cooperation and to have an assessment system to evaluate the performance of smallholders. Other than that, the use of information technology to gather and report data of FFB transaction among smallholders will help in efficient data gathering as well as to address the issues on traceability. Malaysia is in the right track towards sustainable production of palm oil via MSPO certification from a broader 
perspective. However, there are several challenges and constraints ahead that need to be addressed effectively especially concerning independent oil palm smallholders. Collaboration between all the stakeholders is important to embrace and adopt MSPO certification and sustainability as the new normal of oil palm management. Continuous effort towards higher standard and quality are necessary to develop MSPO certification to be internationally recognised and to remain relevant globally.

\section{ACKNOWLEDGEMENT}

The authors would like to thank the DirectorGeneral of MPOB for permission to publish this article.

\section{REFERENCES}

Agro Eco and Grolink (2008). Organic Exports, A Way to a Better Life? Export Promotion of Organic Products from Africa. Report publication. http: / / www.grolink. se, accessed on 30 March 2019. 105 pp.

Ainie, K; Kushairi, A and Choo, Y M (2015). Malaysian sustainable palm oil. Oil Palm Bulletin No. 71: 1-7.

Amekawa, Y (2013). Can a public GAP approach ensure safety and fairness? A comparative study of Q-GAP in Thailand. The J. Peasant Studies, 40(1): 189217.

Augier, P; Gasiorek, M and Lai, T C (2005). The impact of rules of origin on trade flows. Economic Policy, 20(43): 567-623.

Ayat, K A R; Ramli, A; Faizah, S and Arif, S (2008). The Malaysian palm oil supply chain: The role of the independent smallholders. Oil Palm Industry Economic J. Vol. 8(2): 17-27.

Basiron, Y and Foong, KY (2016). The burden of RSPO certification cost on Malaysian palm oil industry and national economy. J. Oil Palm, Environment and Health, 7: 19-27.

Brandi, C; Cabani, T; Hosang, C; Schirmbeck, S; Westermann, L and Wiese, H (2015). Sustainability standards for palm oil: Challenges for smallholder certification under the RSPO. J. Environment and Development, 24: 292-314.

Brenton, P and Manchin, M (2002). Making the EU Trade Agreements Work: The Role of Rules of Origin. Working Document 183. Centre for European Policy Studies, Brussels. 26 pp.
Byerlee, D and Rueda, X (2015). From public to private standards for tropical commodities: A century of global discourse on land governance on the forest frontier. Forests, 6(4): 1301-1324.

Dankers, C and Liu, P (2003). Environmental and Social Standards, Certification and Labelling for Cash Crops. FAO Commodity and Trade Policy Research Working Paper No. 2. Food and Agriculture Org, Rome. 111 pp.

Defries, R S; Fanzo, J; Mondal, P; Remans, R and Wood, S A (2017). Is voluntary certification of tropical agricultural commodities achieving sustainability goals for small-scale producers? A review of the evidence. Environmental Research Letters, 12(3): 033001.

Edwards, R (2015). Is Plantation Agriculture Good for the Poor? Evidence from Indonesia's Palm Oil Expansion. Working Paper No. 2015/12. Crawford School of Public Policy, Australian National University. 61 pp.

Ferrantino, M (2006). Quantifying the Trade and Economic Effects of Non-tariff Measures. OECD Trade Policy Papers No. 28. OECD Publishing, Paris, DOI: https: / / doi.org / 10.1787 / 837654407568 $70 \mathrm{pp}$.

Fontaine, D; Gaspart, F and De Frahan, B H (2008). Modelling the impact of private quality standards on the fresh fruit and vegetable supply chains in developing countries. Paper presented at the $12^{\text {th }}$ EAAE Congress - People, Food and Environments: Global Trends and European Strategies. Gent, Belgium. 26-29 August 2008.

Garcia, M and Poole, N (2004). The development of private fresh produce safety standards: Implications for developing Mediterranean exporting countries. Food Policy, 29(3): 229-255.

Humphrey, J (2006). Policy implications of trends in agribusiness value chains. The European J. Development Research, 18(4): 572-592.

Kushairi, A; Meilina, O A; Balu, N; Elina, H; Mohd Nor Izuddin, Z B; Razmah, G; Shamala, $S$ and Ghulam, K A P (2019). Oil palm economic performance in Malaysia and $R \& D$ progress in 2018. J. Oil Palm Res. Vol. 31(2): 165-194.

Kushairi, A; Soh, K L; Azman, I; Elina, H; Meilina, O A; Zanal, B M N I; Razmah, G; Shamala, S and Parveez, G K A (2018). Oil palm economic performance in Malaysia and R\&D progress in 2017. J. Oil Palm Res. Vol. 30(2): 163-195. 
Laila, K; Subasingae, R and Philips, M (2011). Aquaculture Farmer Organizations and Cluster Management: Concepts and Experiences, FAO Fisheries and Aquaculture Technical Paper No. 563. FAO, Rome. 104 pp.

Morley, D (2015). RSPO, the global standard for sustainable palm oil. Agro Food Industry Hi-tech, 26(6): 29-30.

Murphy, D J (2014). The future of oil palm as a major global crop: Opportunities and challenges. J. Oil Palm Res. Vol. 26(1): 1-24.

Malaysian Palm Oil Board (2018). Overview of the Malaysian oil palm industry 2018. http://bepi. mpob.gov.my/images / overview / Overview_of_ Industry_2018.pdf, accessed on 1 December 2019.

Nia, K H; Pieter, G and Astrid, O (2015). Sustainability certification and palm oil smallholders' livelihood: A comparison between scheme smallholders and independent smallholders in Indonesia. International Food and Agribusiness Management Review, 18(3): 25-48.

Parthiban, K; Nurhana, B; Khairuman, H; Hamdan, A B; Wahid, O; Shahrun, N K; Zamri, M S and Nurhanani, M (2017a). Monitoring and reporting of oil palm fresh fruit bunch (FFB) transactions among independent smallholders and dealers: An analysis of a case study in Selangor, Malaysia. Oil Palm Industry Economic J. Vol. 17(2): 68-81.

Parthiban, K; Tan, S P; Siti, M A; Idris, A S; Ayatollah, K; Khairuman, H; Hamdan, A B and Wahid, O (2017b). Knowledge assessment of basal stem rot disease of oil palm and its control practices among recipients of replanting assistance scheme in Malaysia. International J. Agricultural Research, 12(2): 73-81.

Phillips, M; Subasinghe, R; Clausen, J; Yamamoto, K; Mohan, C V; Padiyar, A and Funge-Smith, S (2008). Aquaculture production, certification and trade: Challenges and opportunities for the smallscale farmer in Asia. Aquaculture Asia Magazine, 13(1): 5-8.

Potts, J; Lynch, M; Wilkings, A; Huppe, G; Cunningham, M and Voora, V (2014). The State of Sustainability Initiatives Review 2014: Standards and the Green Economy. International Institute for Sustainable Development (IISD) and the International Institute for Environment and Development (IIED). Manitoba, Canada and London, United Kingdom. 354 pp.

Rival, A and Levang, P (2014). Palms of Controversies: Oil Palm and Development Challenges. Center for International Forestry Research (CIFOR), Bogor, Indonesia. $59 \mathrm{pp}$. 


\title{
JOURNAL OF OIL PALM RESEARCH
}

\author{
GUIDE TO AUTHORS \\ (for more details, kindly surf http://jopr.mpob.gov.my)
}

\section{Types of Manuscript}

1. Regular article

Definition: Full-length original empirical investigations, consisting of introduction, materials and methods, results and discussion, conclusions. Original work must provide references and an explanation on research findings that contain new and significant findings.

Preferable Size: Preferably not exceeding 5000 words (excluding the abstract, references, tables and/or figures)

\section{Short communication}

Definition: Significant new information to readers of the Journal in a short but complete form.

Preferable Size: Preferably not exceeding 2000 words, and is intended for rapid publication. They are not intended for publishing preliminary results or to be a reduced version of Regular papers.

\section{Review article}

Definition: Critical evaluation of materials about current research that have already been published by organising, integrating, and evaluating previously published materials. Re-analyses as meta-analysis and systemic reviews are encouraged. Review articles provide systemic overview, evaluation and interpretation of research in a given field. Preferable Size: Preferably not exceeding 4000 words.

\section{Language}

The paper must be in British English.

\section{Keywords}

Please list not more than five keywords for indexing purposes.

\section{Abstract}

An abstract of not more than 200 words is to accompany the manuscript. The abstract should encapsulate the research objective(s), the methodology and findings.

\section{Typing}

- The font size should be 12 pt Times Roman doubledspaced with $4 \mathrm{~cm}$ margin on A4 size paper.

- Words to be printed in italics should be italicised.

- Use MS Word

- Not necessary to format/justify or make article visually attractive because it would be reformatted.

\section{Reference}

- Each reference cited should be from an original source. Secondary sources should be cited together with the original references.

- Authors are to provide hyperlinks to all articles referred to in the List of References.

- The Harvard system of citation should be used in the text with the name of the authors(s) in upper lowercase (Capitalise Each Word) followed by the year of publication in parentheses, e.g. John, B J (2012).

- The reference list should be in alphabetical order by first authors. There is no numbering.

\section{Tables}

- Tables should be on separate sheets and properly numbered. The same applies to figures, diagrams and other illustrations.
- Tables must not duplicate material in text or figures.

- The word 'TABLE' and the remainder of the table heading should be in capitals.

- Each table should have a brief title: explanatory notes should be in the legend, not in the title.

- Tables should only have three horizontal lines.

- Non-significant decimal places in tabular data should be omitted.

- Short or abbreviated column heads should be used and explained if necessary in the legend.

- Table footnotes should be listed in order of their appearance and identified by standards symbols: ${ }^{*}, \ddagger$, $\S$ for three or fewer: for four or more, consecutive superscript lower case letters should be used (e.g. ${ }^{\mathrm{a},}{ }^{\mathrm{b}},{ }^{\mathrm{c}}$, etc.).

- Authors are encouraged to view a recent issue of the Journal for table layouts.

\section{Illustrations}

- All illustrations should be cited consecutively and referred to in the text.

- Original artworks or other images must be submitted with the original copy of the manuscript. Photocopies are not acceptable.

- All photomicrographs should be supplied with a suitable scale.

- All illustrations should be numbered in sequence with Arabic numerals, in order of appearance in the text, as Figure 1, Figure 2, etc. Terms such as 'Chart' or 'Plate' should be avoided.

- The word 'Figure' and the caption should be italicised.

- High resolution digital photographs (>300 dpi) are acceptable.

\section{Units of Measurements}

- Metric units or the International System of Units should be used. Leave space between numbers and units, e.g. 20 ha, $5-8 \mathrm{ml}$, use $\mathrm{kg} \mathrm{m}^{-1}$ and not $\mathrm{kg} / \mathrm{m}$.

\section{Review}

- All manuscripts will be referred to appropriate reviewers. Authors are encouraged to nominate possible reviewers, but the final say would be with the Publisher.

\section{Proofs}

- One set of proofs will be sent to the corresponding author to be checked for printer's errors, and it is the responsibility of the author(s) to submit corrections to the editor within the stipulated time.

\section{Manuscript Submission}

- Manuscripts should be submitted via: https://mc04.manuscriptcentral.com/jopres

- Kindly ensure that the names of authors are not written on the manuscript but are indicated in the electronic submission form provided.

- For a guide on tables/figures and references, please refer to the latest edition of JOPR at: http://jopr.mpob.gov.my 